\section{Paediatric blepharoptosis: a 10-year review}

Eye (2009) 23, 1554-1559; doi:10.1038/eye.2008.311; published online 24 October 2008

Keywords: blepharoptosis; congenital ptosis; brow suspension; levator resection; Fasanella Servat; Mersilene

\section{Introduction}

Blepharoptosis presents significant problems in children-cosmetic, ${ }^{1}$ functional, ${ }^{1,2}$ and psychosocial. ${ }^{3}$ Paediatric ptosis is more challenging than adult ptosis because of extra considerations such as amblyopia, difficulty of examination, surgery under general anaesthetic, and the age at which surgery should be performed. ${ }^{4}$ The most effective procedure to correct ptosis must be selected on the basis of the amount of levator function and degree of ptosis $^{5}$ and demands accurate preoperative assessment. ${ }^{6}$ Even then it remains difficult to gain satisfactory results in patients with severe blepharoptosis. $^{5}$

We report the long term follow-up of the second largest series in the literature of children undergoing ptosis surgery necessitating blepharoptosis correction during a 10-year period.

Materials and methods

Patients

We undertook a 10-year retrospective case note review of patients who underwent blepharoptosis surgery at the Birmingham Children's Hospital between 1993 and 2002. All surgery was performed by or under direct supervision of one surgeon (HW). The resultant database was interrogated for the aetiology of the ptosis; severity; surgical correction; outcome; complications and need for reoperation. Patients with a history of less than 1-month follow-up after the surgery or under 
the care of a different surgeon were excluded from this study. Detailed ophthalmic and orthoptic examination was performed on all patients. Indications for surgery were cosmetic, visual (where the lid occluded the visual axis) or the presence of a significant compensatory head posture. Visual acuity was measured using LogMAR at $3 \mathrm{~m}$ or Snellen chart at $6 \mathrm{~m}$ in the older patients. Tests appropriate for age were used in younger children. Amblyopia was defined as a difference of one line or more on the Snellen chart or its equivalent on visual acuity testing. Anisometropia was defined as a spherical difference of greater than 1 dioptre or astigmatism greater than 1 diopter cylinder between the two eyes. Levator function was assessed by the excursion method. The choice of blepharoptosis operation depended on the criteria shown in Table $1 .^{7}$ The severity of the ptosis and the associated compensatory head posture and occlusion of the visual axis dictated the timing of the surgery. ${ }^{8}$

\section{Surgical technique}

All surgery was performed under general anaesthesia. The anterior approach as described by Collin ${ }^{9}$ was used in all our cases of levator resection. Mersilene mesh was the suspension material of choice in all our cases of brow suspension and was inserted as a Fox pentagon. ${ }^{8} \mathrm{La}$ Mange procedure ${ }^{10}$ was used in two cases of Marcus Gunn jaw winking phenomenon. A two-staged technique was performed with levator transposition initially followed by levator resection at a later date. The Fasanella Servat technique ${ }^{9}$ was used for minimal ptosis with good levator function. None of our patients underwent surgical intervention on the contralateral normal upper lid.

\section{Post-operative assessment}

Post-operatively, the patients were prescribed chloramphenicol ointment t.d.s. for a fortnight. All patients were reviewed at 1-2 weeks post-operatively

Table 1 The choice of ptosis operation according to the amount of preoperative ptosis and levator function

\begin{tabular}{lcl}
\hline $\begin{array}{l}\text { Preoperative } \\
\text { amount of ptosis }\end{array}$ & $\begin{array}{c}\text { Levator function } \\
\text { in mm }\end{array}$ & Type of operation \\
\hline $2 \mathrm{~mm}$ & 10 & Fasanella Servat \\
& $8-9$ & $10-13 \mathrm{~mm}$ LPS resection \\
$3 \mathrm{~mm}$ & $>8$ & $14-17 \mathrm{~mm}$ LPS resection \\
& $5-7$ & $18-22 \mathrm{~mm}$ LPS resection \\
& 4 & $>23 \mathrm{~mm}$ LPS resection \\
$4 \mathrm{~mm}$ & $5-7$ & $>23 \mathrm{~mm}$ LPS resection \\
& $<5$ & Brow suspension \\
\hline
\end{tabular}

LPS = levator palpberae superioris; adapted from Willshaw et al. ${ }^{7}$ and further follow-up was arranged in most patients at 3 months, unless there was a clinical need for earlier review. Most patients with a satisfactory outcome were discharged within 1 year of the operation, provided that there were no other concomitant ophthalmic problems, which required longer follow up.

Various factors including palpebral aperture, skin crease and eyelid contour, corneal exposure, nocturnal lagophthalmos, parents and surgeon's satisfaction were analysed during each post-operative visits. Criteria for success were defined as reoperation rate, complication rate, and parental and surgeon's satisfaction. The degree of operation success was graded as good, fair, or poor result. Table 2 clarifies how this grading was chosen.

\section{Results}

\section{Demographic and patients characteristics}

Between 1993 and 2002, 155 (186 eyes) consecutive children met the inclusion criteria for this study. Twentyone patients were excluded; 3 because of inadequate follow-up post-operatively and 18 had ptosis correction under the care of a different surgeon. Ninety-three (115 eyes) boys and 62 (71 eyes) girls were identified. In $20 \%$ of patients there was bilateral involvement and the left lid was affected in $45.81 \%$ of cases (71 LE; $53 \mathrm{RE}$; $31 \mathrm{BE}$ ). Simple congenital ptosis was identified in 76 children, while 79 had their ptosis as part of a recognised syndrome or had other ocular problems. The mean age at presentation was 46.94 months for both sexes (range for boys: birth -158 months; range for girls: birth -186 months), despite the majority of patients being noticed by the family to have the ptosis at birth or within the first 6 months of life. The database identified 124 patients with myogenic ptosis; 22 with neurogenic ptosis; and 8 with a mechanical cause for their ptosis. One

Table 2 The criteria and different grading of success in blepharoptosis surgery

\begin{tabular}{|c|c|}
\hline $\begin{array}{l}\text { Grade of } \\
\text { success }\end{array}$ & Surgical success criteria \\
\hline Good & $\begin{array}{l}\text { Single operation and good cosmesis (residual ptosis } \\
\text { was less than or equal to } 1 \mathrm{~mm} \text { ) } \\
\text { No complications } \\
\text { Both parents and surgeon were satisfied with } \\
\text { results }\end{array}$ \\
\hline Fair & $\begin{array}{l}\text { Single operation but fair cosmesis } \\
+/- \text { Complications } \\
\text { Either parents or surgeon dissatisfied with results }\end{array}$ \\
\hline Poor & $\begin{array}{l}\text { More than one operation with poor cosmesis } \\
\text { Complications occurred } \\
\text { Both parents and surgeon dissatisfied with results }\end{array}$ \\
\hline
\end{tabular}


patient with aponeurotic dehiscence type of ptosis (following a history of eye trauma) was identified. There were no cases of congenital aponeurotic type of ptosis identified in this cohort (good levator function, high skin crease, and no lid lag). Table 3 illustrates the distribution of patients on the basis of a etiology.

A positive family history of congenital ptosis was elicited in $16.77 \%$ (26 of 155) and 12 patients had previous ptosis surgery. Twenty-two patients (14.19\%) had a concomitant squint and 29 patients $(18.70 \%)$ had a significant refractive error requiring spectacles prescription. Anisometropia was found in 21 patients $(13.54 \% ; 21$ of 155), 16 of whom were found to have astigmatism of greater than 1.00 diopter cylinder. Fortyone patients (20 males; 21 females) were found to have amblyopia. The reasons for amblyopia included strabismus (20 cases), anisometropia (16 cases), stimulus deprivation (3 cases), and a combination of strabismus and anisometropia (2 cases). In three patients, their amblyopia became manifest after the ptosis surgery. One patient developed astigmatism in the operated eye; one developed a squint and in one patient, the reason was not clear (Table 4).

\section{Surgical results}

One hundred and ten (122 eyes) children were treated with a levator resection procedure, 28 (47 eyes) underwent a brow suspension with Mersilene mesh, 15 (15 eyes) with Fasanella Servat procedure and 2 (2 eyes) with La Mange procedure (Table 3). Table 3 demonstrates the type of surgery performed according to the aetiology of the ptosis. Bilateral brow suspension procedure was performed in $67.85 \%$ of patients (19 of 28) compared to $10.91 \%$ (12 of 110) who had bilateral levator resection. None of the patients who had ptosis underwent surgery on the contralateral normal eye.

The mean age of the male group at operation was 71.20 months (range: 6 months-13.9 years) and 66.04 months (range: 11 months-15.8 years) in the female group. The mean age at operation for brow suspension was 43.95 months compared to 78.28 months for Fasanella Servat, and 74.15 months for levator resection surgery. The mean post-operative follow-up was 30.82 months (range: 1 month-10.42 years; SD: 34.48 ) with 84 children completing a minimum of 12 months follow-up. Two patients are still under review; one has multiple complex motility problems related to cerebral palsy and the other

Table 3 The distribution of patients on the basis of aetiology and the different type of surgical procedure according to the aetiology of ptosis

\begin{tabular}{|c|c|c|c|c|c|c|}
\hline \multirow[t]{2}{*}{ Type of ptosis } & \multirow{2}{*}{$\begin{array}{l}\text { No. of } \\
\text { children } \\
\text { (eyes) }\end{array}$} & \multirow{2}{*}{$\begin{array}{l}\text { Sex of } \\
\text { children }\end{array}$} & \multicolumn{4}{|c|}{ Type of operation according to the ptosis aetiology (no. of children (eyes)) } \\
\hline & & & $\begin{array}{l}\text { Levator } \\
\text { resection }\end{array}$ & $\begin{array}{c}\text { Brow suspension } \\
\text { (with Mersilene mesh) }\end{array}$ & $\begin{array}{l}\text { Fasanella } \\
\text { Servat }\end{array}$ & $\begin{array}{c}\text { La } \\
\text { Mange }\end{array}$ \\
\hline Myogenic & $124(154)$ & $80 \mathrm{M} ; 44 \mathrm{~F}$ & $85(96)$ & $25(44)$ & 14 (14) & $0(0)$ \\
\hline (a) Developmental abnormality & $114(136)$ & & $81(90)$ & $19(32)$ & $14(14)$ & $0(0)$ \\
\hline (b) Blepharophimosis & $7(13)$ & & $3(5)$ & $4(8)$ & $0(0)$ & $0(0)$ \\
\hline (c) Orbital fibrosis syndrome & $3(5)$ & & $1(1)$ & $2(4)$ & $0(0)$ & $0(0)$ \\
\hline (d) Double elevator palsy & $0(0)$ & & $0(0)$ & $0(0)$ & $0(0)$ & $0(0)$ \\
\hline Neurogenic & $22(22)$ & $10 \mathrm{M} ; 12 \mathrm{~F}$ & $16(16)$ & $3(3)$ & $1(1)$ & $2(2)$ \\
\hline (a) Third nerve palsy & $12(12)$ & & $9(9)$ & $3(3)$ & $0(0)$ & $0(0)$ \\
\hline (b) Marcus Gunn jaw winking & $8(8)$ & & $6(6)$ & $0(0)$ & $0(0)$ & $2(2)$ \\
\hline (c) Horner's syndrome & $1(1)$ & & $0(0)$ & $0(0)$ & $1(0)$ & $0(0)$ \\
\hline (d) Myasthenia & $1(1)$ & & $1(1)$ & $0(0)$ & $0(0)$ & $0(0)$ \\
\hline $\begin{array}{l}\text { Mechanical } \\
\text { (a) Eyelid or orbital mass }\end{array}$ & $8(9)$ & $3 \mathrm{M} ; 5 \mathrm{~F}$ & $8(9)$ & $0(0)$ & $0(0)$ & $0(0)$ \\
\hline Aponeurotic & $1(1)$ & $1 \mathrm{M} ; 0 \mathrm{~F}$ & $1(1)$ & $0(0)$ & $0(0)$ & $0(0)$ \\
\hline (a) Congenital & $0(0)$ & & $0(0)$ & $0(0)$ & $0(0)$ & $0(0)$ \\
\hline (b) Posttraumatic & $1(1)$ & & $1(1)$ & $0(0)$ & $0(0)$ & $0(0)$ \\
\hline Total number of children (eyes) & 155 (186) & & $110(122)$ & $28(47)$ & 15 (15) & $2(2)$ \\
\hline
\end{tabular}

$\mathrm{M}=$ males; $\mathrm{F}$ = females; figures in parentheses indicate number of eyes and in bold denote total number for a specific category. Aetiology classification table adapted from Ahmadi and Sires. ${ }^{3}$ 
Table 4 Demographic features of patients who developed amblyopia post-operatively

\begin{tabular}{|c|c|c|c|c|c|c|c|c|}
\hline $\begin{array}{l}\text { No. of } \\
\text { patients }\end{array}$ & $\begin{array}{l}\text { Sex of } \\
\text { patient }\end{array}$ & $\begin{array}{c}\text { Age at } \\
\text { presentation } \\
\text { (months) }\end{array}$ & $\begin{array}{l}\text { Age at } \\
\text { surgery } \\
\text { (months) }\end{array}$ & $\begin{array}{l}\text { Type of } \\
\text { ptosis }\end{array}$ & $\begin{array}{l}\text { Type of } \\
\text { surgical } \\
\text { procedure }\end{array}$ & $\begin{array}{l}\text { Reason for } \\
\text { post-operative } \\
\text { amblyopia }\end{array}$ & Treatment & $\begin{array}{l}\text { Amblyopia } \\
\text { treatment } \\
\text { successful }\end{array}$ \\
\hline 1 & M & 10 & 61 & Myogenic & $\begin{array}{l}\text { Levator } \\
\text { resection }\end{array}$ & Unclear & Occlusion & Yes \\
\hline 2 & M & 3 & 46 & Myogenic & $\begin{array}{l}\text { Levator } \\
\text { resection }\end{array}$ & Astigmatism & Glasses + occlusion & Yes \\
\hline 3 & $\mathrm{~F}$ & 4 & 9 & $\begin{array}{l}\text { Myogenic } \\
\text { (blepharophimosis) }\end{array}$ & $\begin{array}{l}\text { Brow } \\
\text { suspension }\end{array}$ & Strabismus & $\begin{array}{l}\text { Had bimedial } \\
\text { recessions }+ \text { occlusion }\end{array}$ & Yes \\
\hline
\end{tabular}

Table 5 The success rate of each surgical type of procedure and the subsequent type of reoperation

\begin{tabular}{|c|c|c|c|c|}
\hline Type of operation & Good & Fair & Poor (reoperation) & $\begin{array}{l}\text { Subsequent type of surgery in the } \\
\text { eyes with a poor outcome }\end{array}$ \\
\hline Levator resection & 88 & 10 & $24(19.67 \%)$ & $\begin{array}{l}19 \text { LPS resection } \\
1 \text { Brow suspension } \\
1 \text { Lid lowering Henderson procedure } \\
2 \text { Reformation of the skin crease } \\
1 \text { Levator tuck }\end{array}$ \\
\hline Brow suspension (with Mersilene mesh) & 32 & 7 & $8(17.02 \%)$ & $\begin{array}{l}6 \text { LPS resection } \\
1 \text { Brow suspension } \\
1 \text { La Mange }\end{array}$ \\
\hline Fasanella Servat & 12 & 0 & $3(20 \%)$ & 3 LPS resection \\
\hline La Mange & 0 & 0 & $2(100 \%)$ & 2 LPS resection \\
\hline Total no. of eyes & $132(70.97 \%)$ & $17(9.14 \%)$ & $37(19.89 \%)$ & 37 \\
\hline
\end{tabular}

LPS $=$ levator palpberae superioris.

had been discharged but represented with a recurrence of ptosis 5 years later. Overall, 70.97\% (132 of 186) lids were successfully corrected with a single operation (Table 5). In 17 lids (9.14\%), the results were fair but no further surgery was carried out. Reoperation was required in $37(19.89 \%)$ lids with the mean time to the second surgery being 32.69 months (SD: 21.90). Six patients with a poor outcome had previous ptosis surgery.

The reoperation rate for levator resection was $19.67 \%$ (24 of 122), 17.02\% (8 of 47) for brow suspension, and $20 \%$ ( 3 of 15) for Fasanella Servat (Table 5) and the mean time for reoperation was 33.22, 38.00, and 31.91 months, respectively. Both cases who had undergone La Mange procedure (after a planned two-step surgical approach) required reoperation with levator resection. Table 5 also illustrates the subsequent type of reoperation in cases with a poor outcome. In $75.68 \%$ (28 of 37) lids with a poor outcome, reoperation achieved the desired cosmetic result. In four lids (excluding the two cases of La Mange), three operations were required. A limitation of our study (being retrospective) was documentation of when the ptosis recurrence became noticeable. Out of the 54 eyes with a fair or poor outcome, the time frame when the lid was observed to drop by the parents was recorded in 28 eyes. The period of lid drop after the initial surgery was noted to have been within
6 months of the operation in $67.85 \%$ (19 of 28 ; mean: 3 months; SD: 2.16). Two patients had been discharged from our care with a satisfactory initial outcome and represented with ptosis recurrence after 5 years from the initial operation; one of these patients is still under review. Eighteen patients underwent secondary procedures (including squint surgery, Y-V plasty for blepharophimosis etc in our centre) while under follow-up for their ptosis.

\section{Complications}

Nocturnal lagophthalmos and superficial punctuate erosions were the most common complications.

However, none of these patients required long-term lubricants beyond a few weeks from the operation. Only one patient had a cosmetically unacceptable high lid position post-operatively and required Henderson's lid lowering surgery ${ }^{11}$ (Muller's myotomy with graded division of levator aponeurotic fibres on the anterior tarsal plate) 18 months after the initial surgery. This was our only case of overcorrection. All the other patients with a poor or fair outcome had been undercorrected. One patient who had undergone La Mange procedure had a stitch granuloma, which required surgical excision. None of the patients who underwent brow suspension suffered exposure or extrusion of the Mersilene mesh. 


\section{Discussion}

The patient demographics are similar to other published studies. ${ }^{1,2}$ The higher frequency of males was also seen in this cohort. Mean age at presentation was 46.94 months for both the boys and girls, despite the majority of patients being noticed by the family to have the ptosis at birth or within the first 6 months of life. This may be explained in various reasons:

(1) our department is a tertiary referral centre, and the patient might have been followed-up in an another centre;

(2) we found a general tendency for parents wanting their children to have surgery just before going to school and were happy to leave the ptosis uncorrected until such time;

(3) some older children presented for cosmetic reasons as they were being teased at school.

Although ptosis surgery is commonly delayed until the child is $3-5$ years, children should be referred early to an Ophthalmologist. Eyes with congenital ptosis, especially unilateral, are more predisposed to develop amblyopia at any stage. ${ }^{12}$ Early examination and followup of patients with congenital ptosis to monitor their visual development is necessary, as refractive errors and strabismus are much more common than in the general population. The incidence of amblyopia in the general population is estimated at $3 \%^{13,14}$ and that of squint to be $1-5 \% .^{15}$ The overall rate of amblyopia found in our group was $26.45 \%$, with $14.19 \%$ having squint and $18.7 \%$ visually significant refractive errors. Anisometropia was the most common refractive error with a high propensity for astigmatism greater than 1 diopter cylinder in the ptotic eye.

Amblyopia was present in 41 children and 3 of these were identified after blepharoptosis surgery. In these three cases, one was found to have an increase in their astigmatism in the operated eye; one developed a squint and in one patient, the cause of the amblyopia was not clear (though stimulus deprivation amblyopia from a swollen lid post-operatively was suspected in a child aged 5 years at the time of surgery-Table 4). Two of these patients had levator resection surgery and one had brow suspension for blepharophimosis syndrome. Postoperative refractive changes after ptosis surgery with amblyogenic potential have been described previously. ${ }^{12,16}$ They can revert back to normal after time $^{12}$ but may persist. ${ }^{16}$ In our patient, the refractive changes persisted necessitating spectacles prescription and short-term amblyopia therapy. It seems that refractive changes are most likely to follow levator resection surgery. ${ }^{12}$ Whitehouse et $a l^{1}$ also noticed the development of strabismus in two of their cases following ptosis surgery. One of our patients developed an esotropia post-operatively. For these reasons we recommend that children undergoing blepharoptosis surgery need monitoring of the vision and require a thorough orthoptic assessment before discharge. If the vision is reduced after the operation, then a cycloplegic refraction is warranted.

There have been several debates in the past whether a ptotic lid in itself can cause amblyopia, in the absence of a refractive error and strabismus. Our experience accords with other studies ${ }^{13,14,17}$ in that three patients had no other likely explanation for amblyopia other than stimulus deprivation amblyopia secondary to the ptosis. The risk of developing stimulus deprivation amblyopia in cases where the pupillary axis is threatened necessitates congenital blepharoptosis correction at an early age. ${ }^{6}$ It is not surprising to find that brow suspension patients were operated at an earlier age (mean: 43.95 months) than the other groups (mean: greater than 74 months), because of the greater severity of the ptosis and the likelihood of the pupil obstructing the visual axis in the former category.

Before 1993, we had noted granuloma formation in four eyelids following brow suspension (reported in 2003). ${ }^{8}$ However, after modifying the technique, there were no further complications. The modified technique consisted of soaking the mesh with gentamicin solution before insertion, the ends of the Mersilene mesh were sutured together (rather than tied) and finally buried under frontalis muscle. We did not experience any of the soft tissue complications encountered in other studies ${ }^{1,18,19}$ and still found our results with the Mersilene mesh very encouraging.

The degree of lagophthalmos is associated with the amount of levator complex resection, the severity of ptosis, and poor levator muscle function. ${ }^{6}$ A large proportion of our patients underwent large resections of the levator muscle (mean amount of resection:15.6 mm). A few of our patients experienced nocturnal lagophthalmos and superficial punctuate erosions and this was slightly more prevalent in the levator resection group $(20 \% ; 22$ of 110$)$ compared to the brow suspension group $(17.86 \% ; 5$ of 28$)$ in our series. However, none of these patients required long-term lubricants beyond a few weeks from the operation.

The success rate of paediatric ptosis surgery has been quoted between $75.3-77 \% .{ }^{1-2}$ In our study, the recurrence of ptosis after the initial surgery was noted to have been within 6 months of the operation in $67.85 \%$ (19 of 28). Two patients had been discharged from our care with a satisfactory initial outcome and represented with ptosis recurrence 5 years after the initial operation. Unlike previous authors, ${ }^{2}$ we did not find that the lid height 6 weeks post-operatively is a stable end point. Our results 
are more in line with the study by Berlin et $a l^{20}$ who found a drop in lid level 2-4 months post-operatively. In their discussion, they postulated that the timing of most lid drops was consistent with the suture absorption rate. ${ }^{20}$ Our results also show a greater reoperation rate than Lee's study ${ }^{2}$ (with a median follow-up of 8.7 months). We believe that this large cohort followed for a mean of 2.57 years gives a more accurate picture of the likely outcome in the surgical management of paediatric ptosis.

In conclusion, our study highlighted three important issues:

(1) the possible development of post-operative amblyopia and strabismus,

(2) the high incidence of refractive errors, strabismus, and amblyopia in this paediatric cohort,

(3) the period of ptosis recurrence.

We therefore recommend monitoring of the vision and a thorough orthoptic assessment post-operatively before discharge in all children undergoing blepharoptosis surgery. A cycloplegic refraction is warranted if the vision is reduced after the operation. The early assessment of patients with congenital ptosis to monitor for the development of amblyopia is necessary (even when surgery is planned for at a later date) because refractive errors and strabismus are present in a much higher percentage than the general population. As the majority of recurrences occurred within 6 months after ptosis surgery in our series, we recommend a minimum follow-up period of 6 months on all paediatric patients undergoing blepharoptosis surgery. Parents and patients should be counselled preoperatively that despite a good initial outcome, there is a possibility of ptosis recurrence later in life.

\section{Acknowledgements}

We thank K Mappouras, Yvonne Mills and the Orthoptic Department, Birmingham Children's Hospital.

\section{References}

1 Whitehouse GM, Grigg JR, Martin FJ. Congenital ptosis: results of surgical management. Aust N Z J Ophthalmol 1995; 23: 309-314.
2 Lee V, Konrad H, Bunce C, Nelson C, Collin JR. Aetiology and surgical treatment of childhood blepharoptosis. $\mathrm{Br} J$ Ophthalmol 2002; 86: 1282-1286.

3 Ahmadi AJ, Sires BS. Ptosis in infants and children. Int Ophthalmol Clin 2002; 42: 15-29.

4 O'donnell B, Codère F, Dortzbach R, Lucarelli M, Kersten R, Rosser P. Clinical controversy: congenital unilateral and jaw-winking ptosis. Orbit 2006; 25: 11-17.

5 Park DH, Choi SS. Correction of recurrent blepharoptosis using an orbicularis oculi muscle flap and a frontalis musculofascial flap. Ann Plast Surg 2002; 49: 604-611.

6 Iljin A, Loba A, Omulecki W, Zieliñski A. Congenital blepharoptosis: part I. Evaluation of the results of surgical treatment for congenital blepharoptosis. Acta Chir Plast 2003; 45: 8-12.

7 Willshaw H, Scotcher S, Beatty S. A Handbook of Paediatric Ophthalmology. Pensord Press: United Kingdom, 2000.

8 Sharma TK, Willshaw H. Long term follow-up of ptosis correction using Mersilene mesh. Eye 2003; 17: 759-761.

9 Collin JRO. A Manual of Systemic Eyelid Surgery, 2nd edn. Churchill Livingstone: New York, 1989.

10 Manner RM, Rosser P, Collin JRO. Levator transposition procedure. A review of 35 cases. Eye 1996; 10: 539-594.

11 Henderson JW. Relief of eyelid retraction: a Surgical Procedure. Arch Ophthalmol 1965; 74: 205-216.

12 Kumar S, Chaudhuri Z, Chauhan D. Clinical evaluation of refractive changes following brow suspension surgery in pediatric patients with congenital blepharoptosis. Ophthalmic Surg Lasers Imaging 2005; 36: 217-227.

13 Dray JP, Leibovitch I. Congenital ptosis and amblyopia: a retrospective study of 130 cases. J Pediatr Ophthalmol Strabismus 2002; 39(4): 222-225.

14 Anderson RL, Baumgartner SA. Amblyopia in ptosis. Arch Ophthalmol 1980; 98: 1068-1069.

15 Anderson RL, Baumgartner SA. Strabismus in ptosis. Arch Ophthalmol 1980; 98: 1062-1067.

16 Beneish R, Williams F, Polomeno RC, Little JM, Ramsey B. Unilateral congenital ptosis and amblyopia. Can J Ophthalmol 1983; 18: 127-130.

17 Hornblass A, Kass LG, Ziffer AJ. Amblyopia in congenital ptosis. Ophthalmic Surg 1995; 26: 334-337.

18 Mehta P, Patel P, Olver JM. Functional results and complications of Mersilene mesh use for frontalis suspension ptosis surgery. $\mathrm{Br}$ J Ophthalmol 2004; 88 361-364.

19 Kemp EG, James CR, Collin JR. Brow suspension in the management of ptosis: an analysis of over 100 cases. Trans Ophthalmol Soc UK 1986; 105: 84-87.

20 Berlin AJ, Vestal KP. Levator aponeurosis surgery. A retrospective review. Ophthalmology 1989; 96: 1033-1036. 